\title{
No association between 25-hydroxyvitamin D levels and prediabetes in Brazilian patients. A cross-sectional study
}

\author{
Ausência de associação entre níveis de 25-hidroxivitamina D e pré-diabetes em \\ pacientes brasileiros. Um estudo transversal
}

\author{
Guilherme de Vieira Giorelli', Lívia Nascimento de Matos", Amir Saado', Vera Lúcia Soibelman"I, Cristiane Bitencourt Diasıv \\ Clinical Medicine Service, Hospital do Servidor Público Estadual de São Paulo, São Paulo, Brazil
}

\begin{abstract}
'MD. Master's Student. Hospital do Servidor Público Estadual de São Paulo (HSPE), São Paulo, Brazil. "MD, MSc. Attending Physician, Department of Cardiology, Universidade Federal de São Paulo (Unifesp), São Paulo, Brazil.

'"MD. Head of the Clinical Medicine Service, Hospital do Servidor Público Estadual de São Paulo (HSPE), São Paulo, Brazil.

"MD, MSc, PhD. Attending Physician,

Department of Clinical Medicine, Hospital do Servidor Público Estadual de São Paulo (HSPE), São Paulo, Brazil.
\end{abstract}

\section{KEY WORDS:}

Vitamin D.

Glucose intolerance.

Prediabetic state.

Hyperglycemia.

Diabetes mellitus.

\section{PALAVRAS-CHAVE:}

Vitamina D.

Intolerância à glucose.

Estado pré-diabético.

Hiperglicemia.

Diabetes mellitus.

\begin{abstract}
CONTEXT AND OBJECTIVE: Several studies have evaluated the role of low 25 -hydroxyvitamin D (25OHD3) in the pathogenesis of type 2 diabetes (T2DM) and have presented controversial results. The metabolic processes that culminate in T2DM begin under prediabetic conditions. Our aim was to analyze the association between 25OHD3 and glucose metabolism in individuals who were free from but at elevated risk of diabetes.
\end{abstract}

DESIGN AND SETTING: Cross-sectional study at a tertiary hospital.

METHODS: Anthropometric and laboratory profiles were determined in patients with one or more of the following risk factors: hypertension; body mass index (BMI) $\geq 25 \mathrm{~kg} / \mathrm{m}^{2}$; waist circumference $>80 \mathrm{~cm}$ for women and $>94 \mathrm{~cm}$ for men; first-degree relatives with diabetes; women with large-for-gestational-age newborns or with gestational T2DM; HDL-cholesterol (high density lipoprotein) $<35 \mathrm{mg} / \mathrm{dl}$; and triglycerides $>250 \mathrm{mg} / \mathrm{dl}$. The patients were divided into two groups: one with prediabetes (abnormal fasting plasma glucose or oral glucose tolerance test) and the other with normal glucose (euglycemic).

RESULTS: There was no statistically significant difference between the prediabetic group $(n=38)$ and euglycemic group ( $n=15)$ regarding age $(66.4 \pm 10.6$ versus $62.6 \pm 9.1$ years), gender ( 52.6 versus $73.3 \%$ female) and BMI (30.1 \pm 4.61 versus $\left.27.9 \pm 4.7 \mathrm{~kg} / \mathrm{m}^{2}\right)$. Low serum levels of $25 \mathrm{OHD} 3$ were found in both groups, without any statistically significant difference between them ( $29.1 \pm 11.8$ versus $26.87 \pm 9.2 \mathrm{ng} / \mathrm{dl})$. CONCLUSION: There was no association between $250 \mathrm{HD} 3$ levels and the clinical or laboratorial variables analyzed.

\section{RESUMO}

CONTEXTO E OBJETIVO: Vários estudos já avaliaram o papel da 25-hidroxivitamina D (25OHD3) na patogênese do diabetes tipo 2 (DM2) e apresentaram resultados controversos. Os processos metabólicos que culminam no DM2 se iniciam no pré-diabetes. Nosso objetivo foi analisar a associação da 25OHD3 com o metabolismo glicêmico em indivíduos sem diagnóstico mas com alto risco para diabetes.

TIPO DE ESTUDO E LOCAL: Estudo transversal em hospital terciário.

MÉTODOS: Medidas antropométricas e laboratoriais foram determinadas em pacientes com um ou mais dos fatores de risco: hipertensão; índice de massa corpórea $(I M C) \geq 25 \mathrm{~kg} / \mathrm{m}^{2}$; circunferência abdominal $>80 \mathrm{~cm}$ no sexo feminino e $>94 \mathrm{~cm}$ no sexo masculino; parentes de primeiro grau com diabetes; mulheres com filho nascido grande para idade gestacional ou com DM2 na gravidez; colesterol HDL (high density lipoprotein) < $35 \mathrm{mg} / \mathrm{dl}$ e triglicerídeo > $250 \mathrm{mg} / \mathrm{dl}$. Os pacientes foram divididos em dois grupos: um com pré-diabetes (glicemia de jejum ou teste de tolerância oral à glicose alterados) e outro com glicose normal (euglicêmicos).

RESULTADOS: Entre pré-diabéticos $(n=38)$ e euglicêmicos $(n=15)$ não houve diferença estatística na idade (66,4 \pm 10,6 versus $62,6 \pm 9,1$ anos), gênero (52,6 versus 73,3\% feminino) e IMC (30,1 \pm 4,61 versus $\left.27,9 \pm 4,7 \mathrm{~kg} / \mathrm{m}^{2}\right)$. Baixos niveis séricos de $25 \mathrm{OHD} 3$ foram encontrados nos dois grupos, sem diferença estatística entre eles $(29,1 \pm 11,8$ versus $26,87 \pm 9,2 \mathrm{ng} / \mathrm{dl})$.

CONCLUSÃO: Não houve associação entre os níveis de 250HD3 e as variáveis clínicas e laboratoriais analisadas. 


\section{INTRODUCTION}

The presence of vitamin D receptors (VDRs) has been described in pancreas $\beta$ cells, adipose tissue and muscle tissue. Some studies on animals have suggested that vitamin D is involved in the synthesis and secretion of insulin, which might indicate that lower serum 25-hydroxyvitamin D (25OHD3) could have an impact on type 2 diabetes (T2DM). ${ }^{1,2}$

Twelve million Brazilians presented T2DM in 2011, according to official Brazilian government data, and the prevalence of low serum 25OHD3 has increased all over the world in the last few years. Recently, low serum 25OHD3 has been considered to be a worldwide public health issue due to its impact on many diseases. ${ }^{3}$ Despite great sunlight exposure in Brazil, low serum 25OHD3 has been reported. Saraiva et al. ${ }^{4}$ and Genaro et al. ${ }^{5}$ found unsuitable serum concentrations in $42 \%$ of the elderly in the city of São Paulo and $24 \%$ of osteoporotic women. In healthy teenagers and young adults, the prevalence was $60 \%$ and $50 \%$ respectively. ${ }^{6,7}$

Since prediabetes is an early stage of T2DM in which the metabolic process has already started, prevention efforts at this stage have greater impact in mitigating the development of T2DM. ${ }^{8,9}$ Several clinical studies have evaluated the role of low 25OHD3 in the pathogenesis of T2DM, but with controversial results. ${ }^{10-15}$ Recently, a study has looked into prediabetes and 25OHD3 in a representative population in the United States. This study reported that low serum 25OHD3 levels were associated with prediabetes in that population, with a strong correlation when vitamin D levels were lower than $17 \mathrm{ng} / \mathrm{ml}^{16}$

To try to prove the association between vitamin $\mathrm{D}$ and glucose metabolism, Davidson et al. conducted a randomized study on vitamin D replacement in patients with prediabetes and hypovitaminosis $\mathrm{D}$, and demonstrated that vitamin $\mathrm{D}$ replacement taken for one year did not have any benefit in relation to glucose metabolism. ${ }^{17}$

\section{OBJECTIVE}

Since the findings regarding the association between vitamin $\mathrm{D}$ levels and glucose metabolism continue to be conflicting, and because so far no studies on prediabetes and vitamin $\mathrm{D}$ have been produced in any South American country, we focused on analyzing vitamin $\mathrm{D}$ levels in subjects who were free from diabetes but at elevated risk of T2DM and the correlation with glucose metabolism, in a tertiary-level hospital in the city of São Paulo.

\section{METHODS}

We carried out a cross-sectional study from December 2009 to July 2010 in an outpatient clinic in the Department of Internal Medicine of a tertiary-level hospital in São Paulo, Brazil.

The subjects gave their written informed consent to participate in the study. The study was approved by the research ethics committee of Hospital do Servidor Público Estadual de São Paulo (HSPE) (protocol number 0010.338.000-08).

\section{Inclusion criteria}

The study included individuals who were free from T2DM, but with at least one of the following conditions that have been correlated with higher risk of developing diabetes mellitus: hypertension; body mass index (BMI) $\geq 25 \mathrm{~kg} / \mathrm{m}^{2}$; waist circumference $>80 \mathrm{~cm}$ for women and $>94 \mathrm{~cm}$ for men; first-degree relatives with diabetes; women with large-for-gestational-age newborns or with gestational diabetes mellitus; fasting serum HDL-cholesterol $<35 \mathrm{mg} / \mathrm{dl}$; and triglycerides $>250 \mathrm{mg} / \mathrm{dl}$. Since the Brazilian population is one of the most mixed in the world, ethnic groups were not considered as an inclusion criterion alone.

\section{Exclusion criteria}

The exclusion criteria were defined as follows: prior diagnosis of diabetes mellitus; use of oral hypoglycemic agents or insulin; use of vitamin D or calcium supplementation; and glomerular filtration rate lower than $30 \mathrm{ml} / \mathrm{min} / 1.73 \mathrm{~m}^{2}$. Changes in lifestyle such as treatment for obesity, dyslipidemia, metabolic syndrome or any pathological condition did not constitute exclusion criteria. The only lipid-lowering drugs that were used by some of the study subjects were statins.

The diagnosis of diabetes mellitus was defined as random plasma glucose $>200 \mathrm{mg} / \mathrm{dl}$ for symptomatic patients, and for asymptomatic patients, two results on different days with fasting plasma glucose $(\mathrm{FPG})>125 \mathrm{mg} / \mathrm{dl}$ or two-hour glucose $\geq 200 \mathrm{mg} / \mathrm{dl}$ after oral administration of $75 \mathrm{~g}$ of glucose overload (GTT). Prediabetes was defined as FPG of $100-125 \mathrm{mg} / \mathrm{dl}$ or two-hour glucose of $140-199 \mathrm{mg} / \mathrm{dl}$ after oral administration of $75 \mathrm{~g}$ of glucose overload.

The diagnosis of metabolic syndrome was defined in cases of occurrence of three out of the following five clinical conditions: fasting plasma glucose equal or higher than $100 \mathrm{mg} / \mathrm{dl}$, blood pressure equal or higher than $130 / 85 \mathrm{mmHg}$, triglycerides equal or higher than $150 \mathrm{mg} / \mathrm{dl}, \mathrm{HDL}<40 \mathrm{mg} / \mathrm{dl}$ in males and $<50 \mathrm{mg} / \mathrm{dl}$ in females, and waist circumference $\geq 102 \mathrm{~cm}$ (males) and $\geq 88 \mathrm{~cm}$ (females).

\section{Anthropometric measurements}

All anthropometric measurements were performed by a single observer. Weight and height were assessed while the subjects were wearing light clothes; waist circumference (WC) was measured at the midpoint between the lower costal border of the last rib and the upper border of the iliac crest; and hip circumference (HC) was measured at the level of the greater trochanter.

\section{Laboratory analysis}

Blood samples were collected by means of antecubital venous puncture, after the subjects had spent 12 hours fasting (overnight) and after a five-minute rest in a seated position, in a room with no sun exposure.

Prior to FPG and the two-hour glucose analysis, the subjects were instructed to adhere to a high-carbohydrate diet for three days; not to use any laxative on the day before the test; and not to do any physical exertion just before the test. If individuals presented diarrhea 
during the 48-hour period preceding the two-hour glucose test, it was rescheduled for another day. Individuals were also instructed to avoid walking and they were not allowed to smoke at any time during the test; ingestion of food of any kind was also prohibited during the test. The plasma glucose level was determined using an enzymatic method.

Plasma insulin levels were measured after the 12 hours of overnight fasting by means of an immunometric method in a two-sided solid-phase chemiluminescent assay (Immulite 2000, Siemens TM, Los Angeles, USA). Insulin resistance (IR) was evaluated by means of the formula for homeostasis model assessment $($ HOMA) of IR: HOMA-IR = (glucose $\mathrm{x}$ insulin $) / 22.5$.

Serum uric acid, creatinine, triglyceride and cholesterol concentrations were obtained by means of standard methods. We also evaluated microalbuminuria ( $\mu \mathrm{g} / \mathrm{min}$ ) using the chemiluminescence method, in samples of 24-hour urine. For the estimated glomerular filtration rate (GFR), we used the modification of diet in renal disease (MDRD) formula.

Serum 25-hydroxyvitamin D3 levels were assessed using a radioimmunoassay kit (DiaSorin, Stillwater, MN, USA) in which the intra-assay coefficient of variation was $8.6-12.5 \%$ and the inter-assay coefficient of variation was $8.2-11.0 \%$.

\section{Statistical analysis}

Statistical analyses were performed using the GraphPad Prism 4 software. The statistical significance level was set at $\mathrm{P}<0.05$. Continuous variables were expressed as the mean \pm standard deviation or the median with interquartile range, for the variables with and without normal distribution, respectively. Categorical variables were expressed as percentages. The unpaired $t$ test was used to analyze the difference between two groups, and the Mann-Whitney test was performed when the groups did not have normal distribution. Correlations were obtained through the Pearson or Spearman test, when appropriate.

\section{RESULTS}

We evaluated 53 subjects with a mean age of $65.3 \pm 10.3$ years, of whom 31 (58.5\%) were women. The mean BMI was $29.5 \pm$ $4.7 \mathrm{~kg} / \mathrm{m}^{2}$, WC $99.8 \pm 12.9 \mathrm{~cm}$ and $\mathrm{HC} 104.3 \pm 13.1 \mathrm{~cm}$. The median number of risk factors for diabetes was 4 (4-5). The mean FG was $100.5 \pm 11.2 \mathrm{mg} / \mathrm{dl}$, GTT $132.8 \pm 30.3 \mathrm{mg} / \mathrm{dl}$, HDL-cholesterol $49.9 \pm 12.9 \mathrm{mg} / \mathrm{dl}$, LDL-cholesterol $122.2 \pm$ $36.2 \mathrm{mg} / \mathrm{dl}$, triglycerides $146.2 \pm 7.6 \mathrm{mg} / \mathrm{dl}$ and uric acid $5.3 \pm 2.4 \mathrm{mg} / \mathrm{dl}$. The median serum insulin level was 6.9 (4.616.1) $\mathrm{mUI} / \mathrm{ml}$, median HOMA-IR 1.9 (0.9-4.0), mean serum creatinine $0.9 \pm 0.2 \mathrm{mg} / \mathrm{dl}$, mean glomerular filtration rate from MDRD $69.2 \pm 16.7 \mathrm{ml} / \mathrm{min} / 1.73 \mathrm{~m}^{2}$, median microalbuminuria $7.1(3.6-10.4) \mu \mathrm{g} / \mathrm{min}$ and mean 25OHD3 was $28.4 \pm 11.1 \mathrm{ng} / \mathrm{ml}$.

Thirty-eight patients (71.7\%) had prediabetes and 15 (28.3\%) were euglycemic. Comparing the prediabetes group with the euglycemic group there were no differences in gender distribution (52.6 versus $73.3 \%$ females, respectively), age (66.4 \pm 10.6 versus $62.6 \pm 9.1$ years, respectively), frequency of hypertension (71.5 versus $73.3 \%$, respectively), frequency of dyslipidemia (77.7 versus $66.6 \%$, respectively) or BMI (30.1 \pm 4.6 versus $27.9 \pm 4.7 \mathrm{~kg} / \mathrm{m}^{2}$, respectively), as shown in Table 1.

Compared with the euglycemic group, the prediabetes group presented significantly higher WC $(102.2 \pm 11.8$ versus $94.3 \pm 14.0 \mathrm{~cm}, \mathrm{P}=0.04$, respectively), $\mathrm{HC}(106.9 \pm 10.6$ versus $97.3 \pm 16.3 \mathrm{~cm}, \mathrm{P}=0.02$, respectively), uric acid (6.6 \pm 1.5 versus $5.1 \pm 1.4 \mathrm{mg} / \mathrm{dl}, \mathrm{P}=0.003$, respectively), serum insulin (9.6 (5.4-17.9) versus 5.7 (3.3-9.0) $\mathrm{mUI} / \mathrm{ml}, \mathrm{P}=0.03$, respectively), HOMA-IR (2.6 (1.2-4.7) versus 1.4 (0.7-1.7), $\mathrm{P}=0.01$, respectively) and microalbuminuria (30.6 \pm 88.0 versus $5.2 \pm 3.3 \mu \mathrm{g} / \mathrm{min}$, $\mathrm{P}=0.02$, respectively), as shown in Table 2 . Total cholesterol $(225.0 \pm 36.3$ versus $191.8 \pm 37.6 \mathrm{mg} / \mathrm{dl}, \mathrm{P}=0.005)$, HDL-cholesterol (55.6 \pm 17.6 versus $47.6 \pm 9.9 \mathrm{mg} / \mathrm{dl}, \mathrm{P}=0.04$ ) and LDL-cholesterol $(144.9 \pm 31.0$ versus $112.9 \pm 34.4 \mathrm{mg} / \mathrm{dl}$, $\mathrm{P}=0.003$ ) were higher in the euglycemic group than in the prediabetes group, respectively (Table 2 ).

Low serum levels of 25-hydroxyvitamin D3 were found in both groups, with no difference between the prediabetes and euglycemic groups ( $29.1 \pm 11.8$ versus $26.8 \pm 9.2 \mathrm{ng} / \mathrm{ml}$, respectively). We did not find any correlation between serum 25OHD3 and any anthropometric parameters (weight, BMI, WC and $\mathrm{HC}$ ). In a subanalysis on BMI groups, there was no difference in 25OHD3 levels between subjects with $\mathrm{BMI}<30 \mathrm{~kg} / \mathrm{m}^{2}(\mathrm{n}=30)$ and $\mathrm{BMI} \geq 30 \mathrm{~kg} / \mathrm{m}^{2}$ ( $\mathrm{n}=23$ ): $25.9 \pm 8.0$ versus $30.6 \pm 12.2 \mathrm{ng} / \mathrm{ml}$, respectively.

There was no correlation between 25OHD3 levels and fasting glucose, GTT, serum insulin, HOMA-IR or other laboratory variables. In the whole group, there were 35 patients (66\%) with three or more criteria for metabolic syndrome. We did not find any difference in serum $25 \mathrm{OHD} 3$ between groups with metabolic syndrome $(\mathrm{n}=35)$ and without metabolic syndrome $(\mathrm{n}=18)$ : $29.2 \pm 11.9$ versus $26.6 \pm 9.7 \mathrm{ng} / \mathrm{ml}$, respectively.

Table 1. Clinical characteristics of the prediabetic and euglycemic groups

\begin{tabular}{lccc} 
& $\begin{array}{c}\text { Prediabetic group } \\
\mathbf{n}=\mathbf{3 8}\end{array}$ & $\begin{array}{c}\text { Euglycemic group } \\
\mathbf{n}=\mathbf{1 5}\end{array}$ & $\mathbf{P}$ \\
\hline Age (years) & $66.4 \pm 10.6$ & $62.6 \pm 9.1$ & $\mathrm{~ns}$ \\
Female (\%) & $52.6 \%$ & $73.3 \%$ & $\mathrm{~ns}$ \\
Hypertension (\%) & $71.5 \%$ & $73.3 \%$ & $\mathrm{~ns}$ \\
Dyslipidemia (\%) & $77.7 \%$ & $66.6 \%$ & $\mathrm{~ns}$ \\
Weight & $78.5 \pm 12.6$ & $69.9 \pm 12.7$ & 0.03 \\
Height $(\mathrm{m})$ & $1.61 \pm 0.09$ & $1.58 \pm 0.07$ & $\mathrm{~ns}$ \\
Waist circumference $(\mathrm{cm})$ & $102.2 \pm 11.84$ & $94.3 \pm 14.0$ & 0.04 \\
Hip circumference $(\mathrm{cm})$ & $106.9 \pm 10.6$ & $97.3 \pm 16.3$ & 0.02 \\
\hline Waist circumference/ & $0.9 \pm 0.06$ & $0.9 \pm 0.02$ & $\mathrm{~ns}$ \\
hip circumference & & & \\
Body mass index $\left(\mathrm{kg} / \mathrm{m}^{2}\right)$ & $30.1 \pm 4.61$ & $27.9 \pm 4.7$ & $\mathrm{~ns}$
\end{tabular}

Mean \pm standard deviation. ns = not significant. 
Table 2. Biochemical characteristics of the prediabetic and euglycemic groups

\begin{tabular}{|c|c|c|c|}
\hline & $\begin{array}{l}\text { Prediabetic group } \\
\qquad n=38\end{array}$ & $\begin{array}{l}\text { Euglycemic group } \\
\qquad n=15\end{array}$ & $\mathbf{P}$ \\
\hline Glycemia (mg/dl) & $104.9 \pm 10.1$ & $90.2 \pm 5.3$ & 0.03 \\
\hline GTT 75 g (mg/dl) & $145.5 \pm 23.5$ & $101.7 \pm 21.4$ & $<0.0001$ \\
\hline Cholesterol (mg/dl) & $191.8 \pm 37.6$ & $225.0 \pm 36.3$ & 0.005 \\
\hline HDL cholesterol (mg/dl) & $47.6 \pm 9.9$ & $55.6 \pm 17.6$ & 0.04 \\
\hline LDL cholesterol (mg/dl) & $112.9 \pm 34.4$ & $144.9 \pm 31.0$ & 0.003 \\
\hline Triglycerides (mg/dl) & $156.1 \pm 81.7$ & $121.8 \pm 62.4$ & ns \\
\hline AST $(U / I)$ & $28.6 \pm 6.63$ & $25.6 \pm 6.8$ & ns \\
\hline $\operatorname{ALT}(\mathrm{U} / \mathrm{l})$ & $28.8 \pm 12.8$ & $25.4 \pm 8.7$ & ns \\
\hline Uric acid (mg/dl) & $6.6 \pm 1.5$ & $5.1 \pm 1.4$ & 0.003 \\
\hline Microalbuminuria ( $\mu \mathrm{g} / \mathrm{min})$ & $30.60 \pm 88.0$ & $5.2 \pm 3.3$ & 0.02 \\
\hline Serum insulin (mUl/ml) & $14.83 \pm 17.4$ & $6.6 \pm 4.4$ & ns \\
\hline HOMA-IR & $3.9 \pm 4.7$ & $1.2 \pm 0.5$ & ns \\
\hline WC/height ratio & $0.6 \pm 0.07$ & $0.5 \pm 0.09$ & ns \\
\hline 25OHD3 (ng/ml) & $29.1 \pm 11.8$ & $26.87 \pm 9.2$ & ns \\
\hline
\end{tabular}

Mean \pm standard deviation. $\mathrm{ns}=$ not significant; $\mathrm{GTT}=$ glucose tolerance test; $\mathrm{HDL}=$ high-density lipoprotein; $\mathrm{LDL}=$ low-density lipoprotein; $\mathrm{AST}$ = aspartate aminotransferase; $\mathrm{ALT}=$ alanine aminotransferase; $\mathrm{HOMA}-\mathrm{IR}=$ homeostasis model assessment - insulin resistance.

In our sample, we had 38 patients with age $\geq 60$ years old and 15 with age $<60$ years old. Comparison of 25OHD3 levels between these groups did not show any difference: $29.0 \pm 12.0$ versus $27.1 \pm 8.7 \mathrm{ng} / \mathrm{ml}$, respectively.

\section{DISCUSSION}

There is evidence that $3 \%$ of the human genome is managed by $1.25(\mathrm{OH}) 2 \mathrm{D} 3$, the active form of vitamin $\mathrm{D} .{ }^{18}$ Because of the presence of vitamin $\mathrm{D}$ receptors in several tissues, vitamin $\mathrm{D}$ has been ascribed an important role in neoplasms and in the immune and cardiovascular systems. ${ }^{19-21}$ In addition, other observations indicate that hypovitaminosis $\mathrm{D}$ could have a relationship with the development of metabolic syndrome, including alteration of high-density lipoproteins, triglycerides and blood pressure. ${ }^{22,23}$

Some studies have provided evidence that vitamin D deficiency may contribute directly to or have an adjunct effect on the pathogenesis of diabetes. Although these articles showed different outcomes regarding vitamin $\mathrm{D}$ and diabetes, vitamin $\mathrm{D}$ was correlated with insulin production and secretion, and with regulation of signal transduction and decreased activity of glucose transporter-4 (GLUT 4). ${ }^{1,24,25}$

Scragg et al. confirmed that there was an association between low 25OHD3 and diabetes among non-Hispanic whites and Mexican Americans in the National Health and Nutrition Examination Survey (NHANES) III, and so did Liu et al. in the Framingham Study. ${ }^{10,11}$ The present study and others did not find any association after multivariable adjustments, ${ }^{13,14}$ or in subgroup analyses on women. ${ }^{15}$

Recently, Anoop Shankar et al. ${ }^{16}$ studied the relationship between serum 25-hydroxyvitamin D levels and prediabetes in an American population, using data from NHANES III. The group with prediabetes comprised $42.9 \%$ females versus $55.6 \%$ in the non-prediabetes group. These two groups also presented statistical differences in age and BMI. They found a positive association between serum 25OHD3 and prediabetes only in non-Hispanic white subjects, but not in nonHispanic blacks, Mexican Americans and others. The strongest association was with serum vitamin D lower than $17 \mathrm{ng} / \mathrm{ml}$.

The Brazilian population is one of the most ethnically mixed populations in the world. ${ }^{26}$ We conducted a study on two groups with the same gender distribution, BMI and age. Prediabetic groups had higher weight circumference, hip circumference, serum uric acid, serum insulin, HOMA-IR and microalbuminuria. These data suggest that when prediabetes is diagnosed, metabolic events that are characteristic of diabetes have already begun. Total cholesterol and LDL cholesterol were higher in the euglycemic group probably because of the lesser use of statins.

Our study did not find any association between 25OHD3 and prediabetes. This may be related to the number of individuals in our sample, given that a study that showed this relationship had a population-based sample. ${ }^{16}$ Moreover, despite the low levels of vitamin D in our sample, only $28.3 \%$ had values lower than $20 \mathrm{ng} / \mathrm{ml}$ (data not shown), whereas the correlation with prediabetes that has been demonstrated in the literature occurred with values lower than $17 \mathrm{ng} / \mathrm{ml} .{ }^{16}$ However, in a recent study on 175 obese adolescents, of whom $60 \%$ were euglycemic, $25 \%$ prediabetic and 15\% diabetic, Las Heras et al. did not find any difference in serum 25OHD3 between these groups, or any association with any metabolic parameters, even though the prevalence of low levels of vitamin D was higher in both groups. ${ }^{27}$

Another study, on 150 obese children and adolescents living in the tropics, found vitamin D levels $\geq 20 \mathrm{ng} / \mathrm{ml}$ in $88.6 \%$, with no difference in the prevalence of prediabetes in relation to the group with levels lower than $20 \mathrm{ng} / \mathrm{ml}^{28}$ In spite of our negative results regarding the correlation between prediabetes and vitamin $\mathrm{D}$, measurement of $25 \mathrm{OHD} 3$ levels in patients with prediabetes is important because of the worldwide problem of vitamin D deficiency. However, more studies are necessary in order to reach a conclusion regarding the correlation between prediabetes and vitamin D deficiency.

\section{CONCLUSION}

Our study did not find any association between 25OHD3 and prediabetes. Low serum vitamin D was found in both groups, which is consistent with the worldwide vitamin D deficiency, thus making it difficult to analyze the relationship between prediabetes and vitamin $\mathrm{D}$ deficiency.

Prediabetes is an early stage of diabetes. Any action that could prevent or delay the metabolic process that will lead to diabetes has great importance. Our study contributes towards the scarce literature on vitamin $\mathrm{D}$ and prediabetes by adding information about a South American country with an ethnically mixed population. 


\section{REFERENCES}

1. Bland R, Markovic D, Hills CE, et al. Expression of 25-hydroxyvitamin D3-1alpha-hydroxylase in pancreatic islets. J Steroid Biochem Mol Biol. 2004;89-90(1-5):121-5.

2. Barengolts E. Vitamin D role and use in prediabetes. Endocr Pract. 2010;16(3):476-85.

3. Kimball S, Fuleihan Gel-H, Vieth R. Vitamin D: a growing perspective. Crit Rev Clin Lab Sci. 2008;45(4):339-414.

4. Saraiva GL, Cendoroglo MS, Ramos LR, et al. Influence of ultraviolet radiation on the production of 25 hydroxyvitamin $D$ in the elderly population in the city of São Paulo (23 degrees 34' S), Brazil. Osteoporos Int. 2005;16(12):1649-54.

5. Genaro PS, Pereira GA, Pinheiro MM, Szeinfeld VL, Martini LA. Relationship between nutrient intake and vitamin $D$ status in osteoporotic women. Int J Vitam Nutr Res. 2007;77(6):376-81.

6. Peters BS, dos Santos LC, Fisberg M, Wood RJ, Martini LA. Prevalence of vitamin D insufficiency in Brazilian adolescents. Ann Nutr Metab. 2009;54(1):15-21.

7. Maeda SS, Kunii IS, Hayashi L, Lazaretti-Castro M. The effects of sun exposure on 25-hydroxyvitamin D concentrations in young healthy subjects living in the city of São Paulo, Brazil. Braz J Med Biol Res. 2007:40(12):1653-9.

8. American Diabetes Association. Standards of medical care in diabetes--2010. Diabetes Care. 2010;33 Suppl. 1:S11-61.

9. Knowler WC, Barrett-Connor E, Fowler SE, et al. Reduction in the incidence of type 2 diabetes with lifestyle intervention or metformin. N Engl J Med. 2002;346(6):393-403.

10. Scragg R, Sowers M, Bell C; Third National Health and Nutrition Examination Survey. Serum 25-hydroxyvitamin D, diabetes, and ethnicity in the Third National Health and Nutrition Examination Survey. Diabetes Care. 2004;27(12):2813-8.

11. Liu E, Meigs JB, Pittas AG, et al. Predicted 25-hydroxyvitamin D score and incident type 2 diabetes in the Framingham Offspring Study. Am J Clin Nutr. 2010;91(6):1627-33.

12. Mattila $C$, Knekt $P$, Männistö $S$, et al. Serum 25-hydroxyvitamin D concentration and subsequent risk of type 2 diabetes. Diabetes Care. 2007;30(10):2569-70.

13. Pittas AG, Dawson-Hughes B, LiT, et al. Vitamin D and calcium intake in relation to type 2 diabetes in women. Diabetes Care. 2006;29(3):650-6.

14. Liu S, Song Y, Ford ES, et al. Dietary calcium, vitamin D, and the prevalence of metabolic syndrome in middle-aged and older U.S. women. Diabetes Care. 2005;28(12):2926-32.

15. KnektP, Laaksonen M, Mattila C, et al. Serum vitamin D and subsequent occurrence of type 2 diabetes. Epidemiology. 2008;19(5):666-71.

16. Shankar A, Sabanayagam C, Kalidindi S. Serum 25-hydroxyvitamin $\mathrm{d}$ levels and prediabetes among subjects free of diabetes. Diabetes Care. 2011;34(5):1114-9.

17. Davidson MB, Duran P, Lee ML, Friedman TC. High-dose vitamin D supplementation in people with prediabetes and hypovitaminosis D. Diabetes Care. 2013;36(2):260-6.
18. Bouillon R, Carmeliet $G$, Verlinden $L$, et al. Vitamin D and human health: lessons from vitamin $D$ receptor null mice. Endocr Rev. 2008;29(6):726-76

19. Hewison M. Vitamin D and the immune system: new perspectives on an old theme. Endocrinol Metab Clin North Am. 2010:39(2):365-79.

20. Deeb KK, Trump DL, Johnson CS. Vitamin D signaling pathways in cancer: potential for anticancer therapeutics. Nat Rev Cancer. 2007;7(9):684-700

21. Simpson RU, Hershey SH, Nibbelink KA. Characterization of heart size and blood pressure in the vitamin D receptor knockout mouse. J Steroid Biochem Mol Biol. 2007;103(3-5):521-4.

22. Rejnmark L, Vestergaard P, Heickendorff L, Mosekilde L. Simvastatin does not affect vitamin d status, but low vitamin d levels are associated with dyslipidemia: results from a randomized, controlled trial. Int J Endocrinol. 2010;2010:957174.

23. Scragg R, Sowers M, Bell C. Serum 25-hydroxyvitamin D, ethnicity, and blood pressure in the Third National Health and Nutrition Examination Survey. Am J Hypertens. 2007;20(7):713-9.

24. Pittas AG, Lau J, Hu FB, Dawson-Hughes B. The role of vitamin D and calcium in type 2 diabetes. A systematic review and meta-analysis. J Clin Endocrinol Metab. 2007;92(6):2017-29.

25. Zeitz U, Weber K, Soegiarto DW, et al. Impaired insulin secretory capacity in mice lacking a functional vitamin D receptor. FASEB J. 2003;17(3):509-11.

26. Carvalho-Silva DR, Santos FR, Rocha J, Pena SD. The phylogeography of Brazilian Y-chromosome lineages. Am J Hum Genet. 2001; 68(1):281-6.

27. de las Heras J, Rajakumar K, Lee $\mathrm{S}$, et al. 25-Hydroxyvitamin D in obese youth across the spectrum of glucose tolerance from normal to prediabetes to type 2 diabetes. Diabetes Care. 2013;36(7):2048-53.

28. Poomthavorn P, Saowan S, Mahachoklertwattana P, Chailurkit L, Khlairit P. Vitamin D status and glucose homeostasis in obese children and adolescents living in the tropics. Int J Obes (Lond). 2012;36(4):491-5.

\section{Sources of funding: None \\ Conflict of interest: None}

Date of first submission: May 15, 2013

Last received: December 17, 2013

Accepted: January 29, 2014

\section{Address for correspondence:}

Guilherme de Vieira Giorelli

Av. Atlântica, 1.558

São Paulo (SP) - Brasil

CEP 22751-004

Tel. (+55 21) 2275-1004

Cel. (+55 21) 7944-4443

E-mail: guilherme@giorelli.com.br 